\title{
Evaluation of Welding Residual Stress Characteristics of High-Strength Steel for Offshore Structures Based on Constraint Effect
}

\author{
해양구조용 고강도강의 구속도의 영향에 따른 \\ 용접잔류응력 분포 특성에 관한 연구 \\ Daehee Seong*, Gyubaek An*, and Jong-ung Park** \\ *Department of Naval Architecture \& Ocean Engineering, Chosun University, Gwangju, 61452, Korea \\ **Department of civil Engineering, Chosun University, Gwangju, 61452, Korea \\ †Corresponding author: gyubaekan@chosun.ac.kr
}

(Received January 20, 2022; Revised January 27, 2022; Accepted February 14, 2022)

\begin{abstract}
The characteristics of welding residual stress distribution in high-strength steel for offshore structures were evaluated based on the effect of constraint. It is well known that high-strength steel exhibits a high welding residual stress, and the welding residual stress is a significant factor for evaluating unstable fractures. Test specimens were manufactured by applying different constraint conditions. The constrainted and unconstrainted specimens were welded with the same welding consumables and conditions to evaluate the welding residual stress distribution characteristics. The cutting method was applied to assess the welding residual stresses of both specimens. The results showed that the welding residual stress at the heat-affected zone of the unconstrainted specimen decreased compared with that of the constrainted specimen. However, angular distortion occurred in the unconstrainted specimen instead of reduced welding residual stress.
\end{abstract}

Key Words: Welding residual stress, Constraint, Offshore structure, Cutting method

\section{Research Background and Purpose}

As offshore energy development has been recently conducted in an extreme environment, conditions required for the installment of offshore structures have been reinforced ${ }^{1)}$. Moreover, since most energy resources buried in coastal waters have been extracted, a range of energy resource mining has been extended to waters less than $1,000 \mathrm{~m}$ deep. Such extension of the mining range in waters has intensified environmental conditions for the installment of offshore structures ${ }^{2}$, and these structures have been constantly enlarged to mine a great amount of energy. The establishment of such enlarged offshore structures requires development of high-strength steel for offshore structures and appropriate welding technology $y^{3,4)}$. As offshore structures tend to be built in a fixed way unlike vessels, steel for offshore structures has stricter quality requirements than that for vessels. Particularly, quality management of a welding zone is regarded as a significantly crucial parameter ${ }^{5}$. It is essential to control welding residual stress generated in the welding process among various parameters. High strength steel shows a wide distribution of welding residual stress, which is known as a factor affecting the occurrence and spread paths of unstable fractures ${ }^{6,7)}$ and is significantly considered in numerous reliability tests ${ }^{8-11)}$. It is crucial to control distortion and residual stress generated in the welding process in structures. Welding distortion affects the appearance of structures negatively and has a more negative effect on the safety of these structures. Welding residual stress must be considered to evaluate brittle fracture strength of structures ${ }^{12,13)}$, and structures with a risk of fatigue 
fracture should be evaluated based on welding residual stress according to components ${ }^{14-16)}$. A distribution pattern of welding residual stress might vary according to constraints in the welding processes and structure manufacturing processes. For this reason, the optimal welding conditions should be identified to minimize welding residual stress. This study analyzed distribution properties of welding residual stress in high-strength steel for offshore structures according to the effect of constraints by adjusting welding constraints ${ }^{17,18)}$. To this end, this study produced and used butt joint specimens which applied different constraints. Specifically, this study evaluated distribution properties of welding residual stress by manufacturing (1) a fully constrained specimen and (2) a fully unconstrained specimen and welding both specimens under the same conditions. The cutting method, which is well-known as an experimental method that shows comparatively high reliability, was used to evaluate distribution properties of welding residual stress according to the effect of constraints. Based on the experimental result, this study conducted fundamental research on analyzing different patterns of residual stress generated in both specimens from the perspective of welding mechanics.

\section{Applied Steel and Experimental Method}

\subsection{Applied steel and specimen production}

This study evaluated distribution properties of residual stress in welding zones according to the effect of constraints. In the evaluation process, it manufactured and applied butt joints, which are used the most widely for structure welding, made of high strength steel with a yield stress of 500MPa (E500) for offshore structures. Tables 1 and 2 describe the chemical and mechanical properties of the E500 high strength steel for offshore structures, which was used in this study, respectively. This type of steel shows a comparatively high yield

Table 1 Chemical composition of E500 steel

(wt. \%)

\begin{tabular}{|c|c|c|c|c|c|}
\hline Material & $\mathrm{C}$ & $\mathrm{Si}$ & $\mathrm{Mn}$ & $\mathrm{P}$ & $\mathrm{S}$ \\
\hline E500 & $\geq 0.08$ & $\geq 0.2$ & $\geq 1.6$ & $\geq 0.01$ & $\geq 0.005$ \\
\hline
\end{tabular}

Table 2 Mechanical properties of E500 steel.

\begin{tabular}{|c|c|c|c|c|}
\hline Material & $\begin{array}{c}\text { Yield stress } \\
(\mathrm{MPa})\end{array}$ & $\begin{array}{c}\text { Tensile } \\
\text { stress } \\
(\mathrm{MPa})\end{array}$ & $\begin{array}{c}\text { Elongation } \\
(\%)\end{array}$ & $\begin{array}{c}\text { Charpy } \\
\text { impact test, } \\
-40^{\circ} \mathrm{C},(\mathrm{J})\end{array}$ \\
\hline E500 & 529 & 646 & 19 & 249J \\
\hline
\end{tabular}

strength of $529 \mathrm{MPa}$ compared to other types of steel used for offshore structures. It also shows the average impact toughness of $249 \mathrm{~J}$ at $-40{ }^{\circ} \mathrm{C}$, thereby exhibiting excellent performance for impact toughness at low temperature. Mechanical behaviors in the welding zone vary depending on the effect of constraints. In this regard, this study assumed that welding residual stress and distortion will show different behaviors according to the effect of constraints. Thus, this study represented fully constrained and unconstrained conditions in experiments and investigated these conditions on residual stress and angular distortion. This study produced specimens by using a commercial AWS A5.29 E91T1 welding material, which is generally used in E500 steel for offshore structures. Tables 3 and 4 indicate the chemical and mechanical properties of the welding material respectively. The welding material produced based on overmatching joints showed the yield strength of $580 \mathrm{MPa}$, which was higher by approx. $50 \mathrm{MPa}$ than that of the base metal. The tensile strength and elongation of the welding material were $650 \mathrm{MPa}$ and $20 \%$ respectively. Fig. 1 shows the shape and size of specimens manufactured. Specifically, the specimens were made of $25 \mathrm{~mm}$ thick steel and applied the following conditions: the root gap of $4 \mathrm{~mm}$ and the V-groove shape which has $45^{\circ}$ groove angle and welding length was $400 \mathrm{~mm}$. The entire fully constrained and unconstrained specimens were produced under the same welding conditions, which are indicated in Table 5.

Table 3 Chemical composition of welding consumable (AWS A5.29 E91T1)

$(\mathrm{wt}, \%)$

\begin{tabular}{|c|c|c|c|c|c|}
\hline Welding consumable & $\mathrm{C}$ & $\mathrm{Si}$ & $\mathrm{Mn}$ & $\mathrm{P}$ & $\mathrm{S}$ \\
\hline AWS A5.29 E91T1 & 0.06 & 0.29 & 1.23 & 0.007 & 0.008 \\
\hline
\end{tabular}

Table 4 Mechanical properties of welding consumable (AWS A5.29 E91T1)

\begin{tabular}{|c|c|c|c|}
\hline $\begin{array}{c}\text { Welding } \\
\text { consumable }\end{array}$ & $\begin{array}{c}\text { Yield stress } \\
(\mathrm{MPa})\end{array}$ & $\begin{array}{c}\text { Tensile stress } \\
(\mathrm{MPa})\end{array}$ & $\begin{array}{c}\text { Elongation } \\
(\%)\end{array}$ \\
\hline $\begin{array}{c}\text { AWS A5.29 } \\
\text { E91T1 }\end{array}$ & 580 & 650 & 20 \\
\hline
\end{tabular}

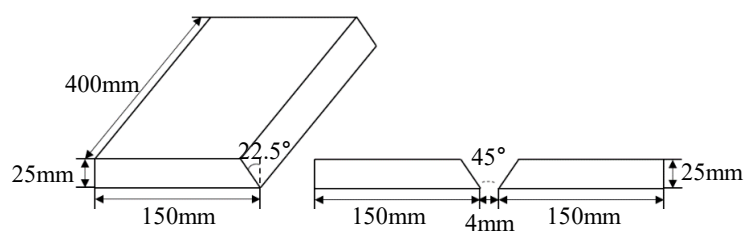

$\begin{array}{ll}\text { (a) specimen dimension } & \text { (b) groove shape }\end{array}$

Fig. 1 Groove shape and dimensions of test specimen 
Table 5 Welding conditions in used

\begin{tabular}{|c|c|c|c|c|c|}
\hline Process & $\begin{array}{c}\text { Pass } \\
\text { No. }\end{array}$ & $\begin{array}{c}\text { Current } \\
(\mathrm{A})\end{array}$ & $\begin{array}{c}\text { Voltage } \\
(\mathrm{V})\end{array}$ & $\begin{array}{c}\text { Speed } \\
(\mathrm{cm} / \mathrm{min})\end{array}$ & $\begin{array}{c}\text { Heat input } \\
(\mathrm{KJ} / \mathrm{cm})\end{array}$ \\
\hline FCAW & 11 & 270 & 30 & 32 & 15 \\
\hline
\end{tabular}

* Welding Position : 1G, * Wire diameter : $\Phi$ 1.2,

* Shielding gas : $100 \% \mathrm{CO}_{2}$

\subsection{Welding residual stress measurement method}

Destructive or non-destructive methods are generally utilized to analyze welding residual stress. This study measured welding residual stress by using the cutting method, which is known as a destructive method that shows high data reliability. Single- and two-axis strain gauges were used in the cutting method, and a distortion rate was sequentially measured based on five densely spaced single-axis strain gauges. Table 6 presents information on the strain gauges used. Fig. 2 shows the constraints and macro sections of the fully constrained and unconstrained specimens. As for the fully constrained specimen, end tabs in the same size as that of specimens were used to fully constrain both ends of the welding start and finish sections. A steel

Table 62 Axis and uniaxial 5-elements strain gauge information in used

\begin{tabular}{|c|c|c|c|c|c|}
\hline $\begin{array}{c}\text { Gauge } \\
\text { type }\end{array}$ & $\begin{array}{c}\text { Gauge } \\
\mathrm{L}\end{array}$ & $\begin{array}{c}\text { Gauge } \\
\mathrm{W}\end{array}$ & $\begin{array}{c}\text { Backing } \\
\mathrm{L}\end{array}$ & $\begin{array}{c}\text { Backing } \\
\mathrm{W}\end{array}$ & Resistance \\
\hline $\begin{array}{c}\text { Axis } \\
\text { (FCA-1) }\end{array}$ & $1 \mathrm{~mm}$ & $0.7 \mathrm{~mm}$ & $\Phi 4.5$ & $\Phi 4.5$ & $120 \Omega$ \\
\hline $\begin{array}{c}\text { Uniaxial- } \\
\text { 5elements }\end{array}$ & $1 \mathrm{~mm}$ & $1.4 \mathrm{~mm}$ & $12 \mathrm{~mm}$ & $4 \mathrm{~mm}$ & $120 \Omega$ \\
\hline
\end{tabular}

backing agent was applied, and a jig was utilized in the welding process to implement the fully constrained conditions. As for the fully unconstrained specimen, both ends of this specimen were tack-welded with end tabs in the minimum size, which facilitated welding, to satisfy the minimum constrain conditions. A ceramic backing agent was applied to allow welding processes in conditions as free as possible. Fig. 3 shows the cutting location and the attachment location for strain gauges for residual stress measurement at welding zones. The distribution of welding residual stress tends to rapidly change near welding zones including heat-affected zone (HAZ). For this reason, strain gauges were densely attached near the HAZ. When residual stress is measured based on the cutting method, it is required to control the heat generated by cutting velocity. The cutting velocity was maintained as $2 \mathrm{~mm} / \mathrm{min}$, and cutting fluid and water were used to control the heat generated in the cutting process. Strain gauges were attached near

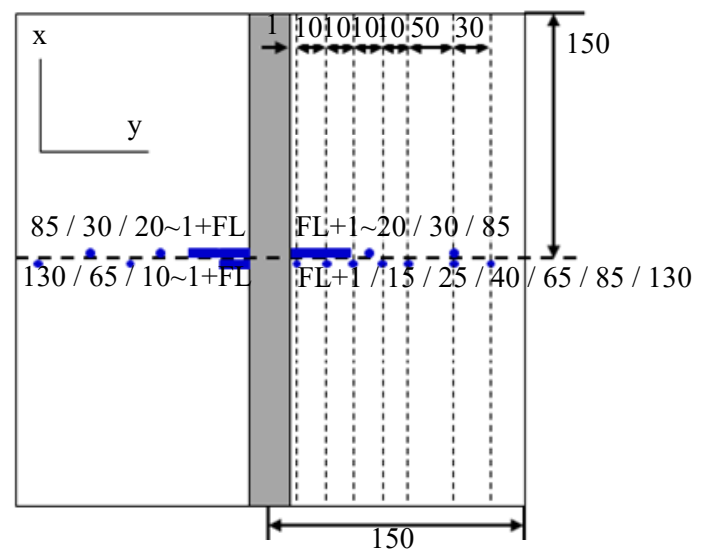

Fig. 3 Strain gauges attachment position of specimen weld

\begin{tabular}{|l|l|l|l|l|}
\hline & Constrainted condition & Backing condition & Marcostructures \\
\hline $\begin{array}{c}\text { Constrainted } \\
\text { weld }\end{array}$ & & &
\end{tabular}

Fig. 2 Constraint condition and marcostructures of specimens 


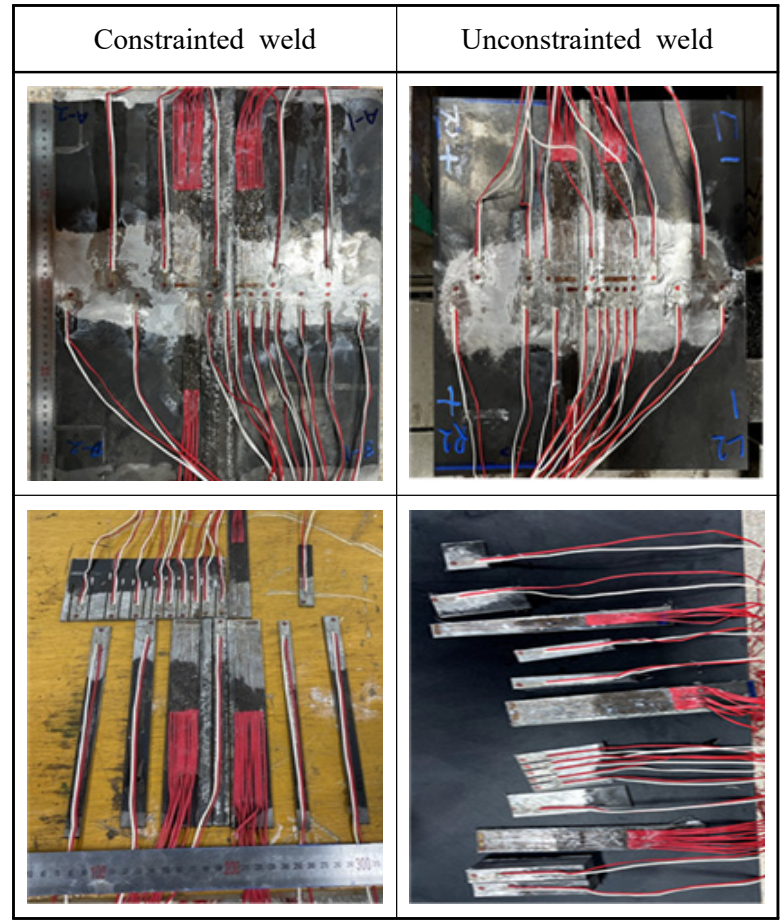

Fig. 4 Cutting process for measurement of welding residual stress with constrainted and unconstrainted weld

the area located at $150 \mathrm{~mm}$, the center in the direction of a welding line. In the HAZ which showed considerable stress change, single-axis 5-elements strain gauges were densely attached from the direction of the fusion line to the width direction of the welding line up to the area located at $20 \mathrm{~mm}$. Two-axis strain gauges were attached at the locations at $25 \mathrm{~mm}, 30 \mathrm{~mm}, 40 \mathrm{~mm}, 65$ $\mathrm{mm}, 85 \mathrm{~mm}$, and $130 \mathrm{~mm}$, respectively, from the direction of the fusion line to the width direction of the welding line. Moreover, strain gauges were attached at the same location on the opposite surface in the direction of the welding line to ensure the reliability of distortion rates measured. Fig. 4 shows the photos of specimens taken after they were cut in the vertical direction to the welding line. The specimens were cut in the direction of the welding line and the direction of thickness to release both residual stress in the vertical direction to the welding line and welding residual stresses in the thickness direction. Cutting was conducted in directions including the thickness direction to obtain only the effect on the surface as much as possible.

\section{Results and Considerations}

\subsection{Results of welding residual stress measured based on the cutting method}

This study measured welding residual stress at weld metal zone and HAZ by applying the cutting method to

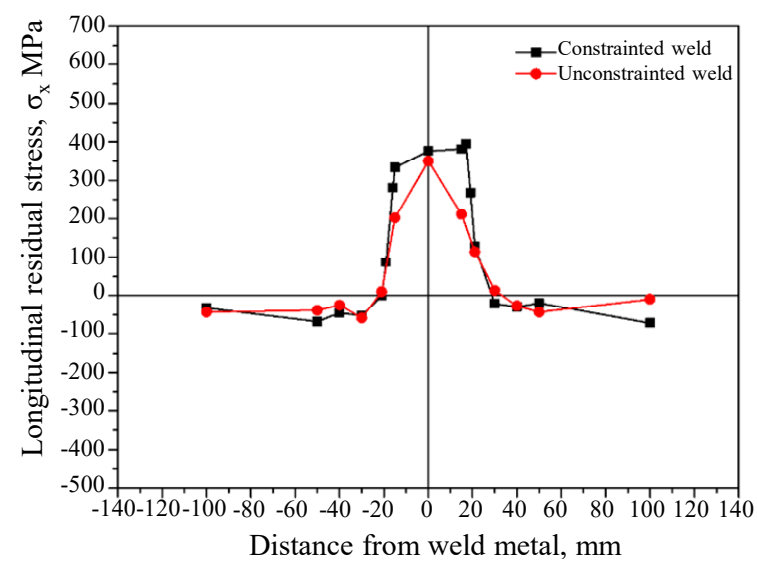

(a) Longitudinal residual stress, $\sigma_{\mathrm{x}}$

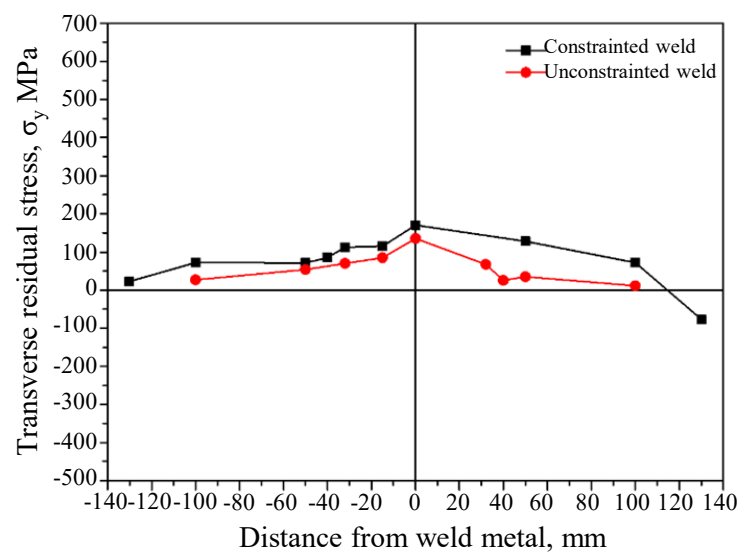

(b) Transverse residual stress, $\sigma_{\mathrm{y}}$

Fig. 5 Weld residual stress by cutting method

analyze the distribution of welding residual stress according to the effect of constraints. Fig. 5(a) shows distribution behaviors in the direction of the welding line. The fully constrained specimen showed tensile residual stress of $379 \mathrm{MPa}$ at weld metal zones and that of 332 $\mathrm{MPa}$ at the location of FL $+1 \mathrm{~mm}$. Tensile stress decreased as the measured part was far from the welding line. The fully constrained specimen showed the typical residual stress distribution of butt joints, which showed compressive residual stress of -106 $\mathrm{MPa}$. In addition, the fully unconstrained specimen showed similar residual stress of $375 \mathrm{MPa}$ at the weld metal zone to that of the fully constrained specimen at the weld metal zone. This result indicated that different external constraints of both specimens did not have a significant constraint effect on welding residual stress at weld metal zones. Moreover, the fully unconstrained specimen showed tensile residual stress of $202 \mathrm{MPa}$ at the location of FL $+1 \mathrm{~mm}$. Tensile stress decreased as the measured part was far from the welding line. Compressive residual stress of - $9 \mathrm{MPa}$ was observed at the location of FL $+100 \mathrm{~mm}$. The fully unconstrained specimen showed a difference of residual stress of approx. 100 
$\mathrm{MPa}$ at the same location of FL $+1 \mathrm{~mm}$ from the fully constrained specimen. The fully constrained specimen with significant constraints showed significant welding residual stress at the HAZ. However, as the measured location was moved to the base metal from the HAZ, both specimens showed a similar distribution of welding residual stress. This result was obtained because residual stress was analyzed as stress distributed at the location of base metal rather than residual stress caused by weld heat. Fig. 5(b) shows distribution behaviors of residual stress in the vertical direction to the welding line. The fully constrained specimen showed tensile residual stress of $170 \mathrm{MPa}$ at the weld metal zones and that of $114 \mathrm{MPa}$ at the location of $\mathrm{FL}+1 \mathrm{~mm}$. Tensile stress decreased as the measured part was far from the welding line. The tensile residual stress was measured as $22 \mathrm{MPa}$ at the location of FL $+130 \mathrm{~mm}$. The fully unconstrained specimen showed tensile residual stress of $135 \mathrm{MPa}$ at the weld metal zones, that of $114 \mathrm{MPa}$ at the location of FL $+1 \mathrm{~mm}$, and that of $22 \mathrm{MPa}$ at the location of FL $+130 \mathrm{~mm}$. It showed similar residual stress at the weld metal zones to that of the fully constrained specimen in the direction of the welding line. The fully constrained specimen showed higher tensile residual stress at the HAZ than the fully unconstrained specimen. Furthermore, both specimens showed similar distribution tendencies of welding residual stress. Welding residual stresses were affected by contraction and expansion at welding zones including weld metal zone and HAZ according to the degree of external constraint. When external constraint was applied severely, the measured parts were constrained by contraction and expansion caused by weld heat. As a result, residual stress at the welding zone increased. On the other hand, areas located far from the welding zone were not affected by weld heat or external constraint. Consequently, residual stress was similar in these areas regardless of the effect of constraints.

\subsection{A relationship between welding residual stress and distortion according to the effect of constraints}

The HAZ showed a greater difference of welding residual stress distribution according to the effect of constraints than the weld metal zone, and the fully unconstrained specimen showed less welding residual stress than the fully constrained specimen. It was found that both specimens showed different welding residual stress according to the effect of constraints under the conditions where the same steel and welding requirements were applied. Accordingly, it was analyzed that welding residual stress reduced in the fully unconstrained specimen appeared in a different form. For this

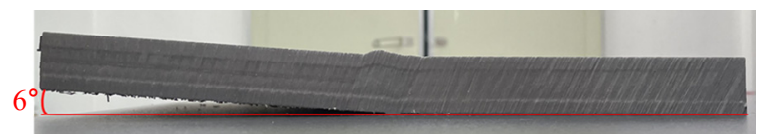

Fig. 6 Angular distortion measurement of unconstrainted weld

reason, this study measured the amount of distortion in both specimens. Generally, both amounts of in-plane and out-of-plane distortion should be considered. However, this study considered only angular distortion, which is out-of-plane distortion. In the fully constrained specimen, angular distortion did not occur at all due to the effect of constraints. On the other hand, angular distortion of approx. $6^{\circ}$ occurred in the fully unconstrained specimen, as shown in Fig. 6. In other words, as the fully unconstrained specimen was not externally constrained, it accompanied free contraction, expansion, and angular distortion caused by weld heat. However, this specimen showed significant welding residual stress at the weld metal zone and the HAZ due to the effect of internal constraints. Yet, the residual stress at the welding zone was reduced in this specimen compared to that in the fully constrained specimen. It was analyzed that the reduced residual stress at the welding zone might appear in the form of in-plane or out-of-plane distortion. This study quantitatively measured only out-of-plane distortion, and it is analyzed that the reduced residual stress energy might have appeared in the form of inplane distortion as well. This study considered only out-of-plane distortion without in-plane distortion.

\section{Conclusions}

This study analyzed the distribution of welding residual stress according to the effect of external constraints. To this end, it manufactured fully constrained and unconstrained specimens by using high-strength steel for offshore structures, which was $25 \mathrm{~mm}$ thick, and compared distribution properties of welding residual stress of these specimens. Based on the analytic results, it derived the following conclusions.

1) Both fully constrained and unconstrained specimens showed similar residual stress at weld metal zones in the direction of a welding line, which was at a similar level to the yield stress of the base metal. Moreover, both specimens showed similar distribution patterns of welding residual stress to those observed at the existing butt joints.

2) The fully unconstrained specimen showed a distribution of reduced welding residual stress at the HAZ than the fully unconstrained specimen. Both specimens showed similar welding residual stress at base metal 
zones, which were unlikely to be affected by weld heat. 3) The fully constrained specimen showed a distribution of reduced welding residual stress at the HAZ according to the effect of constraints, which was observed in the form of in-plane and out-of-plane distortion.

\section{Acknowledgement}

This research was supported by the Basic Science Research Program through the National Research Foundation of Korea (NRF) funded by the Ministry of Education (NRF-2017R1D1A1B04029150).

ORCID: Daehee Seong: http://orcid.org/0000-0002-4245-0355 ORCID: Gyubaek An: http://orcid.org/0000-0003-4274-5716 ORCID: Jong-ung Park: http://orcid.org/0000-0002-0584-7994

\section{References}

1. D. J. Kim, Offshore Plant Industry, J. Korean Soc. Power Syst. Eng. 17 (2013) 12-16. https://doi.org/10.9726/kspse.2013.17.3.012

2. Y. J. Kim, Technology Trend of Offshore Plants, Trans. Korean Soc. Mech. Eng. 53 (2013) 33-37.

3. I. W. Han, Y. H. Park, G. B. An, and Y. H. An, Development Trends of Steel Plates for Ship Building and Off-shore Construction and it's Weldability, J. Korean Weld. Join. Soc. 27(1) (2009) 25-33. https://doi.org/10.5781/KWJS.2009.27.1.025

4. S. J. Lee and C. H. Kim, Statistical Analysis of World Welding Consumables Market( II), J. Weld. Join. 37(6) (2019) 547-554. https://doi.org/10.5781/JWJ.2019.37.6.3

5. Korean Welding and Joining Society, Welding and Joining Handbook, II: Mechanics, Fabrication and Inspection, Korean Welding and Joining Society, Daejeon, Korea (2008) 190-200.

6. G. B. An, J. U. Park, I. W. Han, and W. Woo, Unstable fracture phenomenon of welded joints with weld residual stresses, Theor. Appl. Fract. Mech. 109 (2020) 1-8. https://doi.org/10.1016/j.tafmec.2020.102747

7. J. U. Park, Mechanism and Effects of Welding Residual Stress Mechanism of Welding Residual Stress, J. Korean Weld. Join. Soc. 22(2) (2004) 1-2.
8. J. S. Kim, J. S. Park, and T. E. Jin, Review on the International Joint Researches for Evaluation of Welding Residual Stresses, J. Korean Weld. Join. Soc. 23(6) (2005) 8-17.

9. H. K. Jin, D. J. Lee, and S. B. Shin, Effect of Distance and Restraint Degree between Fillet and Butt Weldment on Residual Stress Redistribution at each Weldment, $J$. Korean Weld. Join. Soc. 28(3) (2010) 287-292. https://doi.org/10.5781/KWJS.2010.28.3.059

10. K. Masubuchi, Analysis of Welded Structures, Pergamon, Oxford, New York (1980) 300-312.

11. P. J. Withers and H. K. D. H. Bhadeshia, Overview Residual Stress Part 2 - Nature and Origin, J. Mater. Sci. Technol. 17 (2001) 366-375. https://doi.org/10.1179/026708301101510087

12. J. D. Almer, J. B. Cohen, and R. A. Winholtz, The effects of residual macrostresses and microstresses on fatigue crack propagation, Metall. Trans. A. 29 (1998), 2127-2136.

13. P. J. Withers and H. K. D. H. Bhadeshia, Residual stress. Part 1 - Measurement techniques, J. Mater. Sci. Technol. 17 (2001) 355-365. https://doi.org/10.1179/026708301101509980

14. Y. Kim and J. H. Lee, Residual Stress Prediction in Multi-layer Butt Weld Using Crack Compliance Method, J. Korean Weld. Join. Soc. 30 (6) (2012) 560-565. https://doi.org/10.5781/KWJS.2012.30.6.560

15. G. B. An, W. Woo, and J. U. Park, Brittle crack-arrest fracture toughness in a high heat-input thick steel weld, Int. J. Fract. Mech. 185 (2014) 179-185. https://doi.org/10.1007/s10704-013-9900-x

16. I. Masaoka, M. Yada, and R. Sasaki, Brittle Fracture Initiation Characteristics of Weld Joint for $80 \mathrm{~kg} / \mathrm{mm}^{2}$ High Strength Thick Plate Steel(Report3) - Effect of Residual Stress and Repair Welding on Brittle Fracture Initiation from Surface Notch in Fusion Line of Welded Joints, J. Japanese Weld. Soc. 44 (11) (2010) 914-9230.

17. J. U. Park, H. W. Lee and H. S. Bang, Effects of mechanical constraints on angular distortion of welding joints, Sci. Technol. Weld Join. 7(4) (2002) 232-239. https://doi.org/10.1179/136217102225004266

18. Y. C. Kim, K. H. Chang and K. Horikawa, Production Mechanism for Out-of-Plane Deformation in Fillet Welding and Investigation of Generality, J. Japanese Weld. Soc. 44, 17(2) (1999) 294-300. 


\title{
해양구조용 고강도강의 구속도의 영향에 따른 \\ 용접잔류응력 분포 특성에 관한 연구
}

\section{Evaluation of Welding Residual Stress Characteristics of High-Strength Steel for Offshore Structures Based on Constraint Effect}

\author{
성 대 희 \\ *조선대학교 선박해양공학과 \\ **조선대학교 토목공학과
}

\section{1. 연구배경 및 목적}

최근 해저에너지 개발 환경이 극한 환경으로 이동함 에 따라 해양구조물의 설치에 필요한 조건들이 강화되 고 있다 ${ }^{1)}$. 또한, 근해에 매장된 에너지자원은 대부분 채굴이 완료되어서 약 $1000 \mathrm{~m}$ 이하의 심해로 확대됨에 따라 해양구조물의 설치 환경은 더욱 열악해지고 있으 며 ${ }^{2)}$, 한번에 많은 양의 에너지를 채굴하기 위하여 해 양구조물의 대형화가 진행되고 있다. 이러한 대형화되 고 있는 해양구조물을 사용 환경에 설치하기 위해서는 해양구조용 고강도강의 개발과 적합한 용접기술의 개발 이 필요하다 ${ }^{3-4)}$. 해양구조용강재는 설치환경이 선박과 달라서 대부분 고정식으로 되어 있기 때문에 보다 엄격 한 품질이 요구되며, 용접부의 품질관리는 무척 중요한 파라메타이다 ${ }^{5)}$. 여러가지 파라메타중에서 용접시 발생 하는 용접잔류응력의 제어는 무척 중요하다. 고강도강 일수록 용접잔류응력이 크게 분포하는 것으로 잘 알려 져 있으며, 용접잔류응력은 불안전파괴의 발생 및 전파 경로에 영향을 미치고 ${ }^{6,7)}$, 각종 신뢰성 평가에 중요한 인자로 알려져 있다-11). 구조물에서 용접 시 발생하는 변형과 잔류응력의 제어는 무척 중요하다. 용접변형은 구조물의 미관에도 영향을 주고 안전성에는 더욱 큰 영 향을 미치게 된다. 한편, 용접잔류응력은 구조물의 취 성파괴강도 평가 시 필수적으로 고려되어야 하며 ${ }^{12,13)}$, 피로파괴의 위험성을 갖는 구조물에 대해서는 용접잔류 응력의 성분별 평가도 중요하다 ${ }^{14-16)}$. 용접잔류응력은 용접프로세스 및 구조물의 제작과정에서 구속하는 방법 에 따라서 그 분포양상이 달라질 가능성이 있어서, 용 접잔류응력의 생성을 최소화하기 위한 최적의 용접조건 의 도출을 필요로 한다. 본 연구에서는 해양구조용 고 강도강을 대상으로 용접 시 구속조건을 변화시켜서 구
속도의 영향에 따른 용접잔류응력 분포 특성을 파악하 기 위하여 ${ }^{17,18)}$, 맞대기 이음부 제작 시 서로 다른 구 속조건을 적용하여 시험편을 제작하였다. (1) 용접 시 시험편을 완전하게 구속시킨 완전구속시험편과 (2) 전혀 구속을 하지 않은 완전비구속시험편을 제작하여 동일한 방법으로 용접을 실시하여 용접잔류응력분포 특성을 평 가하였다. 용접잔류응력의 평가는 비교적 신뢰성이 높 다고 알려진 실험적인 방법인 절단법을 사용하여 구속 도의 영향에 따른 용접잔류응력 분포특성을 평가하였 고, 두 시험편에서 발생하는 잔류응력의 차이가 용접역 학적인 관점에서 어떤 형태로 나타나는가에 대한 기초 적인 연구를 수행하였다.

\section{2. 적용강재 및 실험방법}

\section{1 적용강재 및 시험편제작}

본 연구에서는 해양구조용 고강도강인 항복응력 500 $\mathrm{MPa}$ 급(이하, $\mathrm{E} 500$ ) 강을 사용하여 구조물 용접에 가 장 폭 넓게 사용되는 맞대기 이음부를 대상으로 구속도 의 영향에 따른 용접부 잔류응력 분포 특성을 검토하였 다. 본 연구에 사용한 해양구조용 $\mathrm{E} 500$ 강재의 화학 적 성질과 기계적 물성을 Table 1과 Table 2에 나타 냈다. 항복강도가 $529 \mathrm{MPa}$ 정도로서 해양구조물에 적 용되는 강재 중 항복강도가 높은 강재이며, 충격인성 또한 $-40^{\circ} \mathrm{C}$ 에서 평균 249J로 저온 충격인성이 우수한 성능을 갖고 있다. 구속상태의 영향에 따른 용접부에서

Table 1 Chemical composition of E500 steel

(wt. \%)

\begin{tabular}{|c|c|c|c|c|c|}
\hline Material & $\mathrm{C}$ & $\mathrm{Si}$ & $\mathrm{Mn}$ & $\mathrm{P}$ & $\mathrm{S}$ \\
\hline E500 & $\geq 0.08$ & $\geq 0.2$ & $\geq 1.6$ & $\geq 0.01$ & $\geq 0.005$ \\
\hline
\end{tabular}


Table 2 Mechanical properties of E500 steel.

\begin{tabular}{|c|c|c|c|c|}
\hline Material & $\begin{array}{c}\text { Yield stress } \\
(\mathrm{MPa})\end{array}$ & $\begin{array}{c}\text { Tensile } \\
\text { stress } \\
(\mathrm{MPa})\end{array}$ & $\begin{array}{c}\text { Elongation } \\
(\%)\end{array}$ & $\begin{array}{c}\text { Charpy } \\
\text { impact test, } \\
-40^{\circ} \mathrm{C},(\mathrm{J})\end{array}$ \\
\hline $\mathrm{E} 500$ & 529 & 646 & 19 & 249J \\
\hline
\end{tabular}

의 역학적 거동은 다르게 나타나며, 특히 용접잔류응력 과 변형은 구속의 영향에 따라서 다른 거동을 할 것으 로 예상되어 본 연구에서는 완전구속 상태와 완전비구 속 상태를 실험적으로 재현하여 잔류응력 및 각변형의 영향을 검토하였다. 시험편 제작에 사용된 용접재료는 해양구조용 $\mathrm{E} 500$ 강재에 범용적으로 사용되는 $\mathrm{AWS}$ A5.29 E91T1의 상용 용접재료를 적용하였다. 용접재 료의 화학적 성질 및 기계적 성질은 Table 3, Table 4에 나타냈다. 용접재료의 항복강도는 모재 대비 약 $50 \mathrm{MPa}$ 정도 높은 $580 \mathrm{MPa}$ 오버매칭 이음부로 제작되었다. 용접재료의 인장강도와 연신율은 각각 $650 \mathrm{MPa}, 20 \%$ 의 특성을 갖고 있다. 시험편 제작을 위한 시험편의 형 상 및 사이즈는 Fig. 1에 나타냈으며, 두께 $25 \mathrm{~mm}$ 강재

Table 3 Chemical composition of welding consumable (AWS A5.29 E91T1) $(\mathrm{wt}, \%)$

\begin{tabular}{|c|c|c|c|c|c|}
\hline Welding consumable & $\mathrm{C}$ & $\mathrm{Si}$ & $\mathrm{Mn}$ & $\mathrm{P}$ & $\mathrm{S}$ \\
\hline AWS A5.29 E91T1 & 0.06 & 0.29 & 1.23 & 0.007 & 0.008 \\
\hline
\end{tabular}

Table 4 Mechanical properties of welding consumable (AWS A5.29 E91T1)

\begin{tabular}{|c|c|c|c|}
\hline $\begin{array}{c}\text { Welding } \\
\text { consumable }\end{array}$ & $\begin{array}{c}\text { Yield stress } \\
(\mathrm{MPa})\end{array}$ & $\begin{array}{c}\text { Tensile stress } \\
(\mathrm{MPa})\end{array}$ & $\begin{array}{c}\text { Elongation } \\
(\%)\end{array}$ \\
\hline $\begin{array}{c}\text { AWS A5.29 } \\
\text { E91T1 }\end{array}$ & 580 & 650 & 20 \\
\hline
\end{tabular}

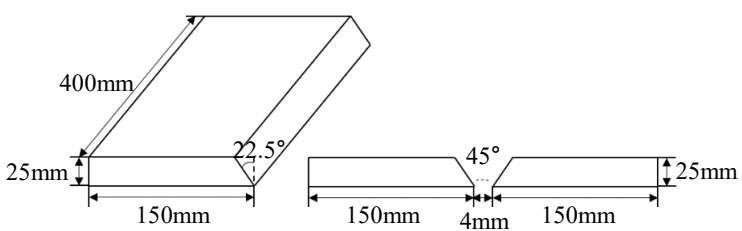

(a) specimen dimension

(b) groove shape

Fig. 1 Groove shape and dimensions of test specimen

Table 5 Welding conditions in used

\begin{tabular}{|c|c|c|c|c|c|}
\hline Process & $\begin{array}{c}\text { Pass } \\
\text { No. }\end{array}$ & $\begin{array}{c}\text { Current } \\
(\mathrm{A})\end{array}$ & $\begin{array}{c}\text { Voltage } \\
(\mathrm{V})\end{array}$ & $\begin{array}{c}\text { Speed } \\
(\mathrm{cm} / \mathrm{min})\end{array}$ & $\begin{array}{c}\text { Heat input } \\
(\mathrm{KJ} / \mathrm{cm})\end{array}$ \\
\hline FCAW & 11 & 270 & 30 & 32 & 15 \\
\hline
\end{tabular}

* Welding Position : $1 \mathrm{G}, *$ Wire diameter : $\Phi$ 1.2,

* Shielding gas : $100 \% \mathrm{CO}_{2}$

를 사용하여, 용접길이 $400 \mathrm{~mm}$, 폭 $150 \mathrm{~mm}$ 에 대하여 $\mathrm{V}$-groove 개선형상으로 양면 $45^{\circ}$ 개선각을 적용하여 루트갭 $4 \mathrm{~mm}$ 조건으로 시험편을 제작하였다. 용접조건 은 Table 5 에서와 같이 완전구속시험편과 완전비구속 시험편 모두 동일한 조건으로 제작되었다.

\section{2 용접잔류응력 측정법}

일반적으로 용접잔류응력의 검토에는 파괴적인방법과 비파괴적인방법이 적용되는데, 본 연구에서는 데이터의 신뢰성이 높다고 알려진 파괴적인 방법인 절단법을 이 용하여 용접잔류응력을 측정하였다. 절단법에는 1 축 및 2축 스트레인게이지를 사용하였으며, 5 개의 촘촘한 1 축게이지를 통하여 연속적으로 변형률을 측정하였다. 스트레인게이지의 정보는 Table 6에 나타냈다.

Fig. 2는 완전구속과 완전비구속 시험편의 구속조건

\begin{tabular}{|l|l|l|l|l|l|}
\hline & Constrainted condition & Backing condition & & Marcostructures \\
\hline $\begin{array}{c}\text { Constrainted } \\
\text { weld }\end{array}$ & & & \\
\hline $\begin{array}{c}\text { Unconstrainted } \\
\text { weld }\end{array}$
\end{tabular}

Fig. 2 Constraint condition and marcostructures of specimens

본 논문은 독자의 이해를 돕기위하여 영문논문을 국문으로 번역하여 게재한 논문입니다. 저자는 본 논문으로 연구업적과 같은 실적에 중복으로 지원받거나 인정받을 수 없음을 알려드립니다. 
과 마크로 단면을 나타냈다. 완전구속시험편은 용접 시 단부와 종단부에 시험편과 동일의 크기의 앤드탭으로 양 끝단에 완전구속을 하였으며, 스틸백킹제를 사용하 였고, 용접중에는 지그를 사용하여 완전 구속시킨 상태 에서 용접을 실시하였다. 완전비구속시험편은 용접이 가능한 크기로 최소크기의 앤드탭을 양 끝단에 가용접 을 통하여 최소한의 구속을 하였다. 세라믹백킹재를 적 용하여 최대한 자유로운 상태에서 용접을 수행하였다. Fig. 3은 용접부의 잔류응력 측정을 위한 절단위치와 스트레인게이지 부착위치를 나타냈다. 용접잔류응력 분 포는 주로 열영향부(HAZ: Heat affected zone)를 포 함한 용접부근방에서 급격한 변화를 갖게 되므로 최대한 $\mathrm{HAZ}$ 근방에 스트레인게이지를 촘촘하게 부착하였다. 절단법에 의한 잔류응력 측정 시 절단속도에 의해서 발 생하는 열의 제어가 필요하다. 절단속도는 $2 \mathrm{~mm} / \mathrm{min}$ 으 로 유지하였으며, 절삭유와 물을 통하여 절단 시 발생 하는 열을 제어하였다. 스트레인게이지는 용접선방향의 중심인 $150 \mathrm{~mm}$ 근방에 부착하였다. 응력변화가 심하게 발생하는 HAZ 영역은 1축 5-elements 스트레인게이 지를 fusion line으로부터 용접선 폭방향으로 $20 \mathrm{~mm}$ 까지 촘촘하게 부착하였다. 2축 스트레인게이지는 fusion line에서 용접선 폭방향으로 $25 \mathrm{~mm}, 30 \mathrm{~mm}, 40 \mathrm{~mm}$, $65 \mathrm{~mm}, 85 \mathrm{~mm}, 130 \mathrm{~mm}$ 위치에 부착하였다. 또한, 용

Table 62 Axis and uniaxial 5-elements strain gauge information in used

\begin{tabular}{|c|c|c|c|c|c|}
\hline $\begin{array}{c}\text { Gauge } \\
\text { type }\end{array}$ & $\begin{array}{c}\text { Gauge } \\
\mathrm{L}\end{array}$ & $\begin{array}{c}\text { Gauge } \\
\mathrm{W}\end{array}$ & $\begin{array}{c}\text { Backing } \\
\mathrm{L}\end{array}$ & $\begin{array}{c}\text { Backing } \\
\mathrm{W}\end{array}$ & Resistance \\
\hline $\begin{array}{c}\text { Axis } \\
\text { (FCA-1) }\end{array}$ & $1 \mathrm{~mm}$ & $0.7 \mathrm{~mm}$ & $\Phi 4.5$ & $\Phi 4.5$ & $120 \Omega$ \\
\hline $\begin{array}{c}\text { Uniaxial- } \\
\text { 5elements }\end{array}$ & $1 \mathrm{~mm}$ & $1.4 \mathrm{~mm}$ & $12 \mathrm{~mm}$ & $4 \mathrm{~mm}$ & $120 \Omega$ \\
\hline
\end{tabular}

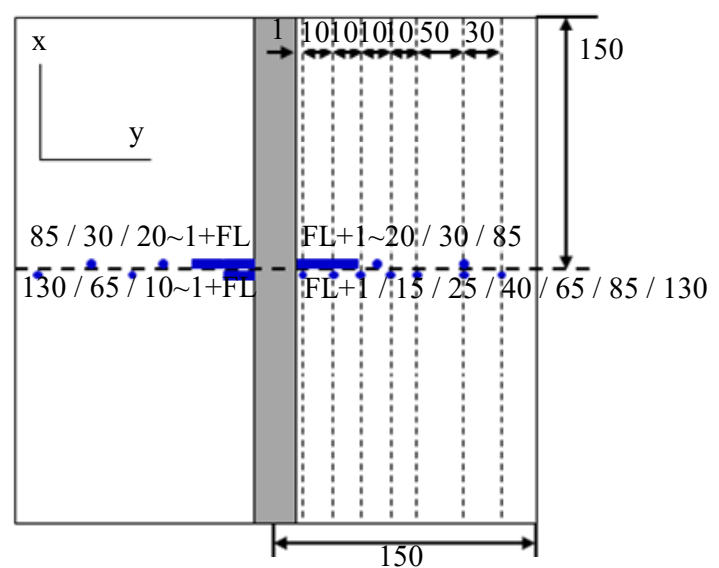

Fig. 3 Strain gauges attachment position of specimen weld

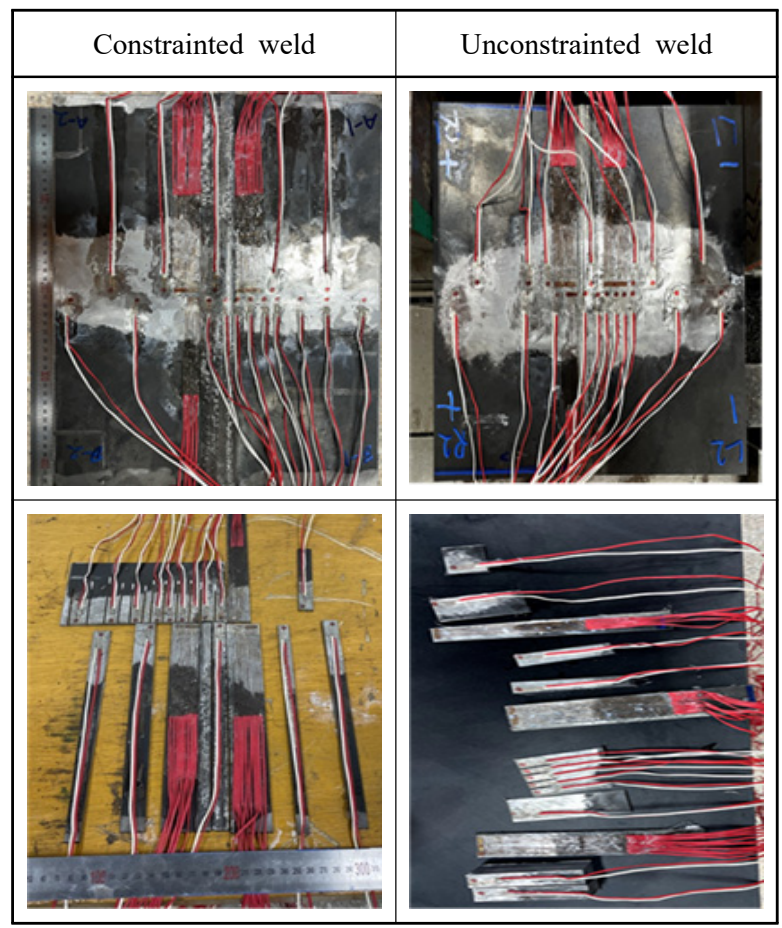

Fig. 4 Cutting process for measurement of welding residual stress with constrainted and unconstrainted weld

접선방향의 반대면에도 동일한 위치에 스트레인게이지 를 부착하여 측정된 변형률값의 신뢰성을 확보하고자 하였다. Fig. 4에서는 용접선 수직 방향으로 절단한 후 의 시험편 사진을 나타냈으며, 용접선방향과 두께방향 으로 절단을 통한 용접선수직방향의 잔류응력과 두께방 향의 용접잔류응력을 모두 해방시켰다. 가능한 표면에 서의 효과만을 얻기 위하여 두께방향으로까지 절단을 수행하였다.

\section{3. 결과 및 고찰}

\section{1 절단법에 의한 용접잔류응력 측정 결과}

구속도의 영향에 따른 용접잔류응력 분포를 검토하기 위하여 절단법에 의하여 용접금속 및 HAZ에 대한 용 접잔류응력 분포를 계측하였다. Fig. 5 (a)에는 용접 선방향 분포 거동을 나타냈다. 완전구속시험편 용접금 속에서 $379 \mathrm{MPa}$ 의 인장잔류응력이 분포하였고, $\mathrm{FL}+$ $1 \mathrm{~mm}$ 부분에서 $332 \mathrm{MPa}$ 의 인장잔류응력이 분포하였으 며, 용접선에서 멀어질수록 인장응력이 감소하여 $\mathrm{FL}+$ $130 \mathrm{~mm}$ 부분에서는 $-106 \mathrm{MPa}$ 압축잔류응력이 분포 하는 전형적인 맞대기 이음부의 잔류응력분포를 나타냈 다. 한편, 완전비구속시험편의 용접금속 에서는 $375 \mathrm{MPa}$ 로 완전구속시험편이 용접금속과 유사한 값을 나타냈 


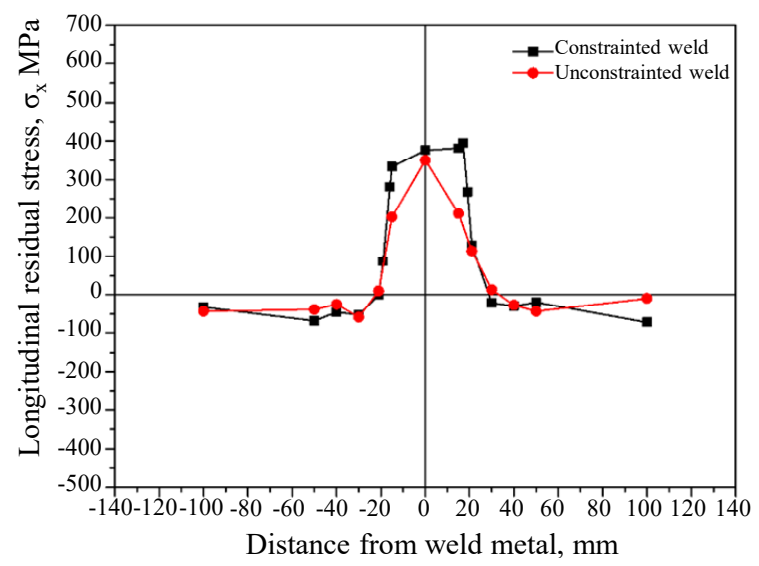

(a) Longitudinal residual stress, $\sigma_{\mathrm{x}}$

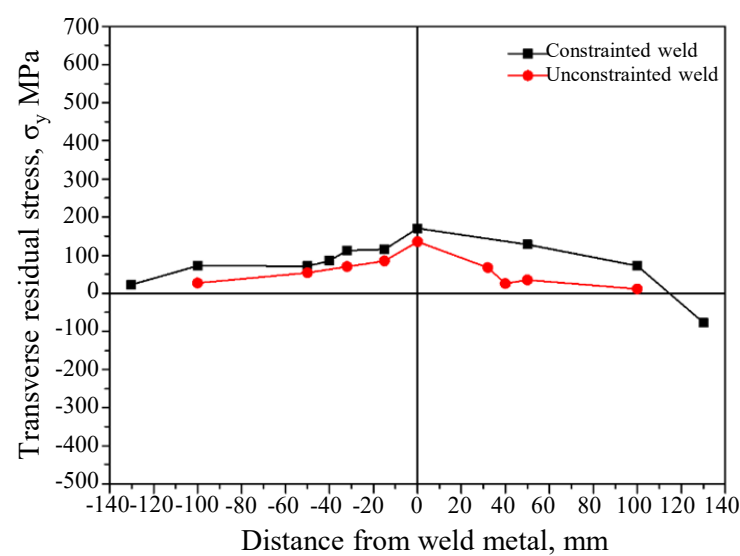

(b) Transverse residual stress, $\sigma_{\mathrm{y}}$

Fig. 5 Weld residual stress by cutting method

다. 외적구속에서는 차이가 있으나, 시험편자체의 구속 효과에 의해서 용접금속의 용접잔류응력에는 큰 차이가 없는 것으로 판단된다. $\mathrm{FL}+1 \mathrm{~mm}$ 에서 $202 \mathrm{MPa}$ 의 인 장잔류응력이 분포하였으며, 용접선에서 멀어질수록 인 장응력이 감소하여, $\mathrm{FL}+100 \mathrm{~mm}$ 에서 $-9 \mathrm{MPa}$ 의 압축 잔류응력이 분포하였다. 완전구속시험편의 경우와 비교 하면 동일한 $\mathrm{FL}+1 \mathrm{~mm}$ 에서 약 $100 \mathrm{MPa}$ 정도의 차이 가 있으며, 구속도가 큰 완전구속의 경우는 $\mathrm{HAZ}$ 에서 비교적 용접잔류응력이 크게 나타나는 것으로 확인 되 었다. 하지만, HAZ에서 모재쪽으로 이동하면 두 시험 편에 대한 용접잔류응력은 거의 유사한 분포를 보였다. 용접열에 의한 잔류응력 보다는 모재 부분에 분포하고 있는 응력으로 판단되어서 유사한 값을 나타낸 것으로 생각된다. (b)에는 용접선수직방향 잔류응력 분포거동 을 나타냈다. 완전구속시험편 용접금속에 $170 \mathrm{MPa}$ 인 장잔류응력이 분포하였다. $\mathrm{FL}+1 \mathrm{~mm}$ 에 $114 \mathrm{MPa}$ 인 장잔류응력이 분포하였으며, 용접선에서 멀어질수록 인 장응력이 감소하여 $\mathrm{FL}+130 \mathrm{~mm}$ 부분에서 $22 \mathrm{MPa}$ 인 장잔류응력이 분포하였다. 완전비구속시험편 용접금속에
는 $135 \mathrm{MPa}$ 의 인장잔류응력이 분포하였고, $\mathrm{FL}+1 \mathrm{~mm}$ 에는 $114 \mathrm{MPa}$ 의 인장잔류응력이 분포하였으며, $\mathrm{FL}+$ $130 \mathrm{~mm}$ 에는 $22 \mathrm{MPa}$ 의 인장잔류응력이 분포하였다. 용 접선방향 잔류응력과 동일하게 용접금속에서는 거의 유 사한 응력값을 나타냈고, $\mathrm{HAZ}$ 에서는 완전구속시험편 의 경우가 높은 인장잔류응력이 분포하는 것으로 나타 났다. 용접잔류응력의 분포경향은 두 방향 모두 유사하 게 나타남을 알 수 있다. 외적구속정도에 따라서 용접 금속 및 HAZ를 포함한 용접부에서는 수축과 팽창에 영향을 받게 된다. 외적구속이 강하게 작용하는 경우는 용접열에 의한 수축과 팽창에 구속을 받게 되어서 최종 적으로 잔류하는 용접부의 응력은 증가하게 되고, 비교 적 용접부에서 멀리 떨어져 용접열의 영향을 받지 않은 곳은 외적구속의 영향을 크게 받지 않게 되어서 구속도 의 영향에 관계없이 거의 유사한 값을 나타내는 것으로 판단된다.

\section{2 구속도의 영향에 따른 용접잔류응력과 변형 과의 관계}

구속도의 영향에 따른 용접잔류응력 분포의 차이는 용접금속 보다 HAZ에서 크게 나타났으며, 완전비구속 시험편이 다소 작은 용접잔류응력을 나타냈다. 동일한 강재와 용접조건에서 구속의 차이에 따라서 용접잔류응 력이 다르게 나타난 것은 완전비구속 시험편의 감소된 용접잔류응력이 다른 형태로 나타났을 것으로 유추되어 서, 두 시험편에 대한 변형량을 측정하였다. 면내변형 량과 면외변형량을 고려해야 하지만, 본 연구에서는 면 외변형인 각변형만을 고려하였다. 완전구속시험편의 경 우는 구속의 영향으로 각변형이 전혀 발생하지 않았으 나, 완전비구속시험편의 경우는 Fig. 6에서와 같이 약 $6^{\circ}$ 정도의 각변형이 발생하였다. 완전비구속시험편은 외 적구속이 없기 때문에 용접열에 의해서 자유롭게 수축 과 팽창 및 각변형이 발생되었다. 또한, 외적구속이 없 음에도 용접잔류응력은 내적구속의 영향으로 용접금속, $\mathrm{HAZ}$ 에서 큰 용접잔류응력이 발생하였다. 하지만, 용 접부에서 완전구속시험편 보다는 감소된 잔류응력이 분 포하였으며, 용접부에서 감소된 잔류응력은 면내 및 면 외 변형의 변화된 형태로 나타날 것으로 판단된다. 본 연구에서는 면외변형만을 정량적으로 측정하였고, 면내

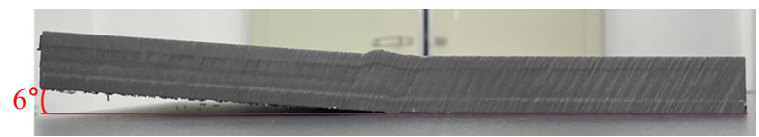

Fig. 6 Angular distortion measurement of unconstrainted weld 
변형의 형태로도 잔류응력의 감소된 에너지는 나타났을 것으로 판단된다. 본 시험 범위에서는 면외변형에 대하 여 검토하였고, 면내변형에 대해서는 고려하지 못 하였다.

\section{4. 결 론}

본 연구에서는 외적구속도의 영향에 따른 용접잔류응 력 분포를 검토하기 위하여 두께 $25 \mathrm{~mm}$ 인 해양구조용 고강도강을 이용하여 완전구속시험편과 완전비구속시험 편을 맞대기 이음부로 제작하여 용접잔류응력분포 특성 을 비교 분석한 결과 아래와 같은 결론을 얻었다.

1) 완전구속과 완전비구속시험편 모두 용접금속에서 의 용접선방향 잔류응력은 거의 유사한 값을 나타냈으 며, 그 값은 모재의 항복응력 정도의 수준이었으며, 용 접잔류응력 분포양상은 종래의 맞대기이음부에서 나타 나는 분포와 유사 하였다.

2) $\mathrm{HAZ}$ 에서의 용접잔류응력은 완전비구속시험편이 완전구속시험편보다 다소 감소된 응력분포를 나타냈으 며, 용접열의 영향이 거의 미치지 못하는 모재에서는 두 시험편에서 유사한 용접잔류응력 값을 나타냈다.

3) 구속의 영향에 따라서HAZ의 용접잔류응력분포는 완전비구속시험편의 경우 감소하였으며, 감소된 용접잔 류응력은 면내외 변형의 형태로 발생하였다.

$$
\text { 후기 }
$$

이 논문은 2021년도 정부(과학기술정보통신부)의 재 원으로 한국연구재단의 지원을 받아 수행된 기초연구사 업임(NO. NRF-2017R1D1A1B04029150)

ORCID: Daehee Seong: http://orcid.org/0000-0002-4245-0355 ORCID: Gyubaek An: http://orcid.org/0000-0003-4274-5716 ORCID: Jong-ung Park: http://orcid.org/0000-0002-0584-7994

\section{References}

1. D. J. Kim, Offshore Plant Industry, J. Korean Soc. Power Syst. Eng. 17 (2013) 12-16. https://doi.org/10.9726/kspse.2013.17.3.012

2. Y. J. Kim, Technology Trend of Offshore Plants, Trans. Korean Soc. Mech. Eng. 53 (2013) 33-37.

3. I. W. Han, Y. H. Park, G. B. An, and Y. H. An, Development Trends of Steel Plates for Ship Building and Off-shore Construction and it's Weldability, J. Korean Weld. Join. Soc. 27(1) (2009) 25-33. https://doi.org/10.5781/KWJS.2009.27.1.025

4. S. J. Lee and C. H. Kim, Statistical Analysis of World Welding Consumables Market( II), J. Weld. Join. 37(6) (2019) 547-554. https://doi.org/10.5781/JWJ.2019.37.6.3
5. Korean Welding and Joining Society, Welding and Joining Handbook, II: Mechanics, Fabrication and Inspection, Korean Welding and Joining Society, Daejeon, Korea (2008) 190-200.

6. G. B. An, J. U. Park, I. W. Han, and W. Woo, Unstable fracture phenomenon of welded joints with weld residual stresses, Theor. Appl. Fract. Mech. 109 (2020) 1-8. https://doi.org/10.1016/j.tafmec.2020.102747

7. J. U. Park, Mechanism and Effects of Welding Residual Stress Mechanism of Welding Residual Stress, J. Korean Weld. Join. Soc. 22(2) (2004) 1-2.

8. J. S. Kim, J. S. Park, and T. E. Jin, Review on the International Joint Researches for Evaluation of Welding Residual Stresses, J. Korean Weld. Join. Soc. 23(6) (2005) 8-17.

9. H. K. Jin, D. J. Lee, and S. B. Shin, Effect of Distance and Restraint Degree between Fillet and Butt Weldment on Residual Stress Redistribution at each Weldment, $J$. Korean Weld. Join. Soc. 28(3) (2010) 287-292. https://doi.org/10.5781/KWJS.2010.28.3.059

10. K. Masubuchi, Analysis of Welded Structures, Pergamon, Oxford, New York (1980) 300-312.

11. P. J. Withers and H. K. D. H. Bhadeshia, Overview Residual Stress Part 2 - Nature and Origin, J. Mater. Sci. Technol. 17 (2001) 366-375. https://doi.org/10.1179/026708301101510087

12. J. D. Almer, J. B. Cohen, and R. A. Winholtz, The effects of residual macrostresses and microstresses on fatigue crack propagation, Metall. Trans. A. 29 (1998), 2127-2136.

13. P. J. Withers and H. K. D. H. Bhadeshia, Residual stress. Part 1 - Measurement techniques, J. Mater. Sci. Technol. 17 (2001) 355-365. https://doi.org/10.1179/026708301101509980

14. Y. Kim and J. H. Lee, Residual Stress Prediction in Multi-layer Butt Weld Using Crack Compliance Method, J. Korean Weld. Join. Soc. 30 (6) (2012) 560-565. https://doi.org/10.5781/KWJS.2012.30.6.560

15. G. B. An, W. Woo, and J. U. Park, Brittle crack-arrest fracture toughness in a high heat-input thick steel weld, Int. J. Fract. Mech. 185 (2014) 179-185. https://doi.org/10.1007/s10704-013-9900-x

16. I. Masaoka, M. Yada, and R. Sasaki, Brittle Fracture Initiation Characteristics of Weld Joint for $80 \mathrm{~kg} / \mathrm{mm}^{2}$ High Strength Thick Plate Steel(Report3) - Effect of Residual Stress and Repair Welding on Brittle Fracture Initiation from Surface Notch in Fusion Line of Welded Joints, J. Japanese Weld. Soc. 44 (11) (2010) 914-9230.

17. J. U. Park, H. W. Lee and H. S. Bang, Effects of mechanical constraints on angular distortion of welding joints, Sci. Technol. Weld Join. 7(4) (2002) 232-239. https://doi.org/10.1179/136217102225004266

18. Y. C. Kim, K. H. Chang and K. Horikawa, Production Mechanism for Out-of-Plane Deformation in Fillet Welding and Investigation of Generality, J. Japanese Weld. Soc. 44, 17(2) (1999) 294-300. 